\title{
Interdisciplinarity and Teacher Education: The Teacher's Training of the Secondary School in Rio de Janeiro-Brazil
}

\author{
Antonio Augusto Fidalgo-Neto ${ }^{1}$, Renato Matos Lopes ${ }^{1}$, \\ José Leopoldo Cerqueira Magalhães ${ }^{2}$, Max Fonseca Pierini'1, Luiz Anastácio Alves ${ }^{1}$ \\ ${ }^{1}$ Laboratory of Cellular Communication, Oswaldo Cruz Institute. Oswaldo Cruz Foundation (FIOCRUZ), Rio de \\ Janeiro, Brazil \\ ${ }^{2}$ Nuta James Bartlet State High School, Rio de Janeiro, Brazil \\ Email: ${ }^{*}$ renatoml@fiocruz.br
}

Received 2 October 2013; revised 2 November 2013; accepted 9 November 2013

Copyright (C) 2014 by authors and Scientific Research Publishing Inc.

This work is licensed under the Creative Commons Attribution International License (CC BY). http://creativecommons.org/licenses/by/4.0/

c) (i) Open Access

\begin{abstract}
This paper investigates the teacher's perception and knowledge about interdisciplinarity on public secondary school in Rio de Janeiro. Among the participants, 101 teachers completed the questionnaire on the subject investigated. All data about the perceptions of teachers were faced with lesson plans prepared by teachers who reported having strong knowledge on interdisciplinary practice. Our results suggest that there is a lack of support in schools, and competence of teachers to develop interdisciplinary approaches in the classroom. In this context, we suggest the use of methodologies such as Problem-Based Learning in teacher training courses in Brazil, as well as encouraging a continuing education of professionals through postgraduate programs.
\end{abstract}

\section{Keywords}

Interdisciplinarity; Teacher Knowledge; Teacher Education; Brazil

\section{Setting the Problem}

According to the Brazilian Academy of Science (ABC), the social, technological and scientific development of the Brazil is related with a reform of the educational structure. In order to achieve this, it would be essential to improve primary and secondary education quality, especially science teaching. Moreover, the university courses should be restructured, in order to promote interdisciplinarity, using flexible curriculums that enrich students’

*Corresponding author.

How to cite this paper: Fidalgo-Neto, A. A., Lopes, R. M., Magalhães, J. L. C., Pierini, M. F., \& Alves, L. A. (2014). Interdisciplinarity and Teacher Education: The Teacher's Training of the Secondary School in Rio de Janeiro-Brazil. Creative Education, 5, 262-272. http://dx.doi.org/10.4236/ce.2014.54035 
scientific (Chaves et al., 2004; Hamburger et al., 2007; National Environmental Policy Act of 1969, 1994).

A subject-centered curriculum prevails in the Brazilian public secondary schools. Therefore, in 2009, the Brazil's Ministry of Education (MEC) proposed a program entitled "Innovative Secondary School”. The program seeks to provide support for curricular innovations for secondary school education in Brazilian public schools. The goal is to search for interdisciplinary articulation focused on the development of knowledge by integrating activities and developing relationships between the constituent axes of secondary school, which are determined by the program as "work, science, technology and culture" (MEC, 2009).

A consistent proposal for curricula organization, including a combined interdisciplinary perspective, focused on knowledge development through information, skills, values and practices, is crucial for the improvement of Brazilian education. Therefore, among other things, political commitment and the technical competence of teachers are necessary factors for success. The results of a study entitled "Teachers in Brazil: obstacles and challenges” (Gatti \& Barreto, 2011), launched by the United Nations Educational, Scientific and Cultural Organization (UNESCO), show more than two million of teachers in primary and secondary education face two major problems: low wages and poor training. Moreover, obsolete teaching techniques are still predominant in Brazilian public and private schools. The teachers are the unique source for information, and the students have to memorize what the teachers say. Students are seen as "blank pages" that must be met by the narration and speech content by teachers (Azer, 2009; Freire, 1987).

The main purpose of this study was to examine the perceptions and knowledge regarding interdisciplinarity by secondary school teachers from public schools in State of Rio de Janeiro. In addition, we sought to understand aspects related to the teacher's training, including their opinions on the conditions that their schools offer for applying an interdisciplinary curriculum.

\section{Interdisciplinarity: An Overview}

Interdisciplinarity has been identified as a desirable direction of research and is being strongly promoted by research funding organizations in Europe and USA (Krishnan, 2009). In today's science, it is very difficult to obtain new findings exclusively through the use of a single discipline (Koizumi, 2004). Technological advances in recent decades have provided significant modifications to our society. The genome project, for example, has allowed scientists the opportunity to study genetic processes on a molecular scale, including the mechanisms of complex biochemical interactions and gene regulations (Tadmor \& Tidor, 2005; Wingreen \& Botstein, 2006). The emerging field of systems biology is also integrating concepts and ideas of life sciences, engineering and computing (Tadmor \& Tidor, 2005). As a result of these processes, it is necessary to broaden the boundaries of traditional scientific disciplines propitiating a wider and more integrated frame to different disciplinary fields of science (Bialek \& Botstein, 2004). In the other words, the rapidly developing fields or research, such as biotechnology, nanotechnology and artificial intelligence, are inherently interdisciplinary (Krishnan, 2009).

A discipline can be defined as any comparatively self-contained and isolated domain of human experience, which possesses its own community of experts (Nissani, 1997). Edgar Morin (Morin, 2000) supports the idea that disciplines are important; however, he claims that it is necessary to place the relevant knowledge associated with disciplines in a broader context (contextualization). On the other hand, many authors and institutions proposed and shows classifications that distinguish terms as "multidisciplinarity", "pluridisciplinarity", and "interdisciplinarity" with objective to organize the multiplicity of forms of interdisciplinary work into a coherent framework (Lattuca, 2003; Nikitina, 2006; Nissani, 1997; OECD, 1972). These classifications are based in accord of the interaction among disciplines in a curriculum and how closely the disciplines bond in the interaction and what is produced as the result of this bonding. In resume, in a multidisciplinary process, the disciplines approach a matter without cooperation between them; there is a juxtaposition of various disciplines, sometimes with no apparent connection between them. Pluridisciplinary work implies some cooperation between disciplines; there is a juxtaposition of disciplines assumed to be more or less related. In interdisciplinarity, the disciplines are totally integrated (Klein, 2006; Nikitina, 2006), and refers to the appropriate combination of knowledge from different specialties to shed new light on an actual problem (Brewer, 1999). Moreover, Nissani (1997) considers that interdisciplinarity is best seen as bringing together distinctive components of two or more disciplines and pointed that in academic discourse, interdisciplinarity typically applies to four realms: knowledge, research, education, and theory. 
Nikitina (2006) defends three strategies for interdisciplinary teaching: contextualizing, conceptualizing and problem-centring. "The first strategy, contextualizing, is a method of embedding any material in the fabric of the time, culture, and personal experience". "The second strategy, conceptualizing, involves identifying core concepts that are central to two or more disciplines (e.g. 'change', 'linearity'), and establishing a rigorous quantifiable connection among them". "The third strategy, problem-centering, involves enlisting the knowledge and modes of thinking in several disciplines (i.e. biology, chemistry, political science, economics) to examine messy real-life problems (such as water pollution, genetic engineering, or AIDS in Africa) that require more on discipline to solve”. In this context, Veronica Boix Mansilla, a co-principal investigator with Howard Gardner in the Interdisciplinary Studies Project at Harvard University, defines interdisciplinary understanding as "the capacity to integrate knowledge and modes of thinking in two or more disciplines to produce a cognitive advancemente.g., explaining a phenomenon, solving a problem, creating a product, raising a new question-in ways that would have been unlikely through single disciplinary means" (Mansilla, 2005).

In Brazil, the concept of interdisciplinary practice is included in the National Curriculum Guidelines for secondary school. In the opinion of the National Education Council, interdisciplinarity assumes the existence of an axis of integration that can be the object of knowledge, a research project or an intervention plan, to be implemented within the framework of education (Brasil, 1998). Therefore, an interdisciplinary activity is a process of exchange and cooperation, focusing on the coordination and integration of disciplinary knowledge when addressing a particular issue, object of study or research setting, as well as a product of this bonding among disciplines. However, there is little evidence that current educational systems are adequately fulfilling these goals and, apparently, the interdisciplinary paradigm and contextualization of school knowledge are still poorly prevalent in the Brazilian educational system (Fazenda, 2002; Lopes, Silva Filho, Marsden, \& Alves, 2011).

\section{Material and Methods}

\subsection{Participants}

We enrolled 101 secondary school teachers from public schools in the State of Rio de Janeiro. All subjects participating in this study were volunteers and signed an informed consent document. The questionnaire was anonymous and no specific information about workplace was collected.

\subsection{Questionnaire and Qualitative Analysis}

The questionnaire was designed based on literature review and validate through a pilot study (Augusto \& Caldeira, 2007; Hill \& Hill, 2005) We sought the following information about "interdisciplinarity" and "interdisciplinary teaching”: a) teachers' perceptions regarding the knowledge on the theme; b) details of initial or continued education of these professionals, specifically if there was interdisciplinary training at any level of their education; c) teachers' perceptions about the importance of interdisciplinarity in teaching practices; d) aspects related to the pedagogical and schools' environment to facilitate the construction of interdisciplinary teaching activities; e) the existence and frequency of interdisciplinary practices in their schools.

In addition, we performed a qualitative analysis of teachers' knowledge regarding interdisciplinarity. For this, we randomly selected 15 teachers who stated to have solid knowledge about the theme, and request them to prepare a lesson plan with an interdisciplinary basis. Each teacher has the freedom to choose the theme in your lesson plan.

The following criteria were used to evaluate the lesson plans: 1) objectives to be achieved; 2) the subjects and the number of teachers involved and the development of activities in the classroom; 3) teaching strategy or methodology to be adopted, and 4) assessment and evaluation of the learning process. These criteria were chosen based on didactics (BIE, 2008; Bordenave \& Pereira, 2005; Serdyukov \& Ryan, 2008).

\subsection{Statistical Analysis}

The averages, deviations, medians, chi-square and the construction of graphs were performed using GraphPad Prism version 5.00 for Windows, GraphPad Software, San Diego California USA (www.graphpad.com). Results were considered significant when $p<0.05$. 


\section{Results}

\subsection{Questionnaire Analysis}

Information on teacher training was required in the first part of the questionnaire and detailed data are presented in Table 1. The results showed that the faculty participants had different levels of training. Forty teachers are trained in humanities, 25 in Math and 36 in Natural Sciences.

The second part of the questionnaire aimed to evaluate the teachers' perceptions, knowledge and applications on interdisciplinarity (Table 2). All teachers responded that they know what is interdisciplinary. However, 10 said they had a little knowledge about the topic, 55 said they knew about it well, and 36 considered that has a broad knowledge about the theme "interdisciplinarity".

The Table 2 shows the results of teachers' answers when asked about their initial training. Thirty-eight teachers said they did not have interdisciplinary training during their undergraduate studies, and 63 said they had had such training.

Considering the 63 teachers, 23 considered that they had had a poor training regarding interdisciplinary aspects (bad or regular). Moreover, 30 teachers said they had good training, and 10 others, a very good training. A more detailed analysis, with data crossing from the highest level of training (higher degrees) and interdisciplinary training during the period, showed that teachers with higher degrees (graduate) had more interdisciplinary practices (Chi-square, $p=0.0013$ ) (Figure 1 ).

All participants responded that the interdisciplinarity is an important pedagogical approach in the educational context (Table 2). Eighty-one teachers believed that "interdisciplinary teaching" is very important, 18 believed they had little importance and 2 said that interdisciplinarity is not very important.

Table 2 also shows the perception of teachers regarding the academic organization and the school's physical space in the development of an interdisciplinary education. Only two teachers answered that the organization and academic environment facilitate interdisciplinary practice. Moreover, 79 teachers considered that these same

Table 1. Total number of participating teachers, divided by gender, age range, level of education, workload, time of teaching, salary range, educational background and training.

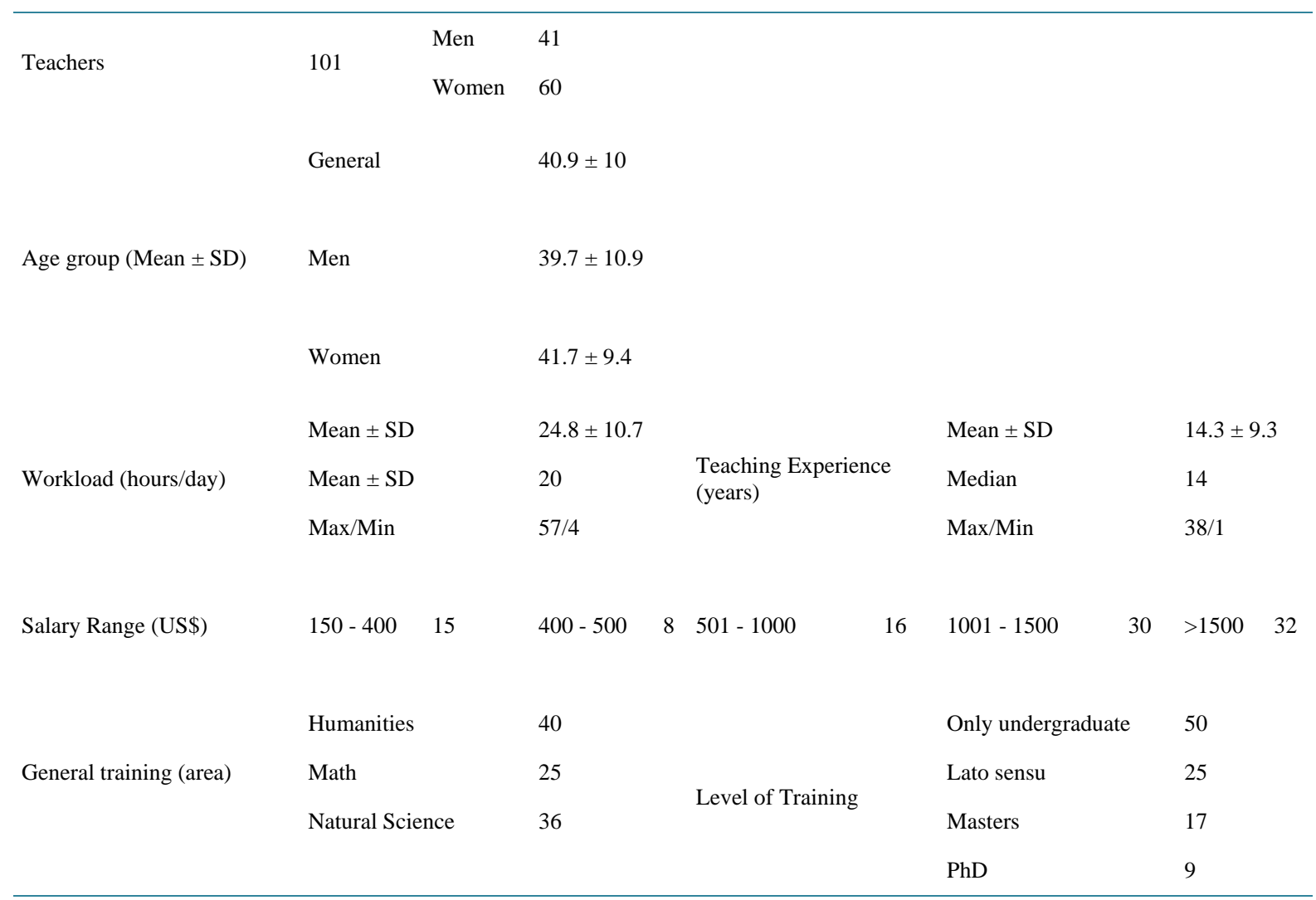


factors do not favor (34 teachers) or favor too little (45 teachers) the construction of interdisciplinary activities in their institutions. Eighteen teachers affirmed that the organization and academic environment did little to help foster them.

Table 2 shows the responses of teachers on the existence and frequency of interdisciplinary developmental practices in the institutions where they teach. Ten teachers answered that there was no interdisciplinary practice, and 5 stated that such practices are common. Eighty-six teachers responded that interdisciplinarity teaching in their schools are rare.

When asked if they use interdisciplinary practice when they taught classes, 59 teachers answered yes and 42 answered that they did not (Table 2). However, these results are inconsistent with the frequency in their instituitions (Table 2) and with the analysis of lesson plans developed by some teachers (Table 2).

\subsection{Qualitative Analysis: Evaluation of Lesson Plans}

To make a qualitative analysis of teachers' knowledge about interdisciplinary, the 15 lesson plans submitted by

Table 2. Evaluation the teachers' perceptions, knowledge and applications on interdisciplinarity.

\begin{tabular}{|c|c|c|c|c|c|}
\hline \multirow{2}{*}{ Interdisciplinary Knowledge stated by the teachers } & No & Little & Well & \multicolumn{2}{|c|}{ Very well } \\
\hline & 0 & 10 & 55 & \multicolumn{2}{|l|}{36} \\
\hline \multirow{3}{*}{ Teachers' perceptions about their initial training } & Disciplinary & \multicolumn{4}{|c|}{ Interdisciplinary } \\
\hline & & Bad & Regular & Good & Very good \\
\hline & 38 & 13 & 10 & 30 & 10 \\
\hline \multirow{2}{*}{$\begin{array}{l}\text { Importance in adopting interdisciplinary practices } \\
\text { in their activities }\end{array}$} & Too little & \multicolumn{2}{|c|}{ Little importance } & \multicolumn{2}{|c|}{ Very important } \\
\hline & 2 & \multicolumn{2}{|l|}{18} & \multicolumn{2}{|l|}{81} \\
\hline \multirow{2}{*}{$\begin{array}{l}\text { Does Academic organization and physical space } \\
\text { supports interdisciplinary education? }\end{array}$} & No & \multicolumn{2}{|c|}{ Too little somewhat } & \multicolumn{2}{|c|}{ Very good } \\
\hline & 34 & 45 & & 0 & \\
\hline \multirow{2}{*}{ Frequency of interdisciplinary practices in their institutions } & \multicolumn{3}{|c|}{ There is no interdisciplinary practices } & Rare & Common \\
\hline & 10 & & & 86 & 5 \\
\hline \multirow{2}{*}{$\begin{array}{l}\text { Development of interdisciplinary activities } \\
\text { by the participating teachers }\end{array}$} & Yes & \multicolumn{2}{|c|}{ No } & & \\
\hline & 59 & \multicolumn{2}{|c|}{42} & & \\
\hline
\end{tabular}

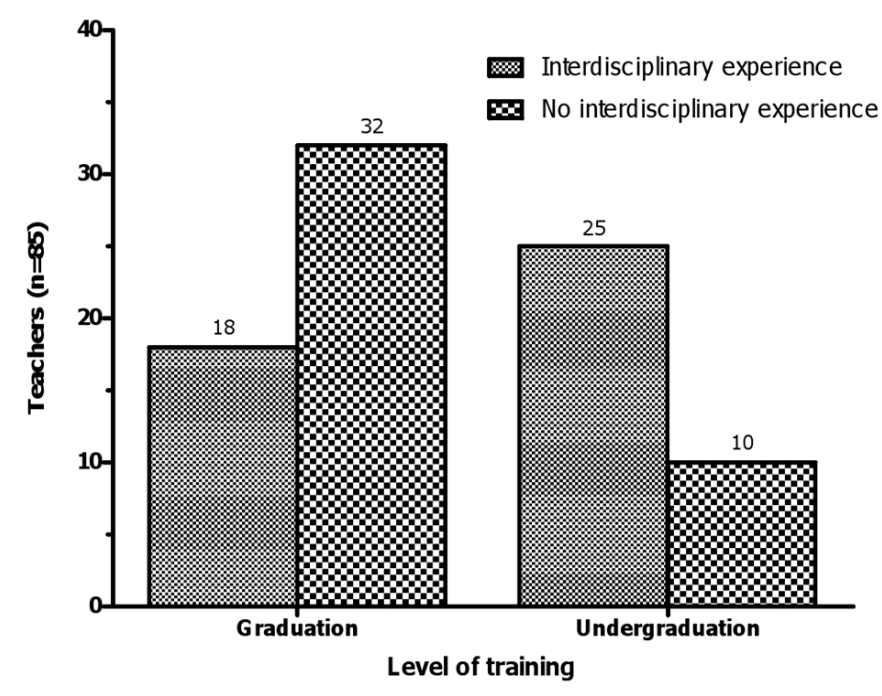

Figure 1. Influence of undergraduate and graduate teachers and their interdisciplinary experiences during training. (Chi-square, $p=0.0013$ ). 
teachers were compiled and analyzed according to criteria previously described. The relationship between learning objectives and evaluation, the number of teachers involved in the development of classes, and the use of teaching strategies or methodologies that facilitate an interdisciplinary approach were considered in the analysis of lesson plans (Table 3).

Only four teachers were careful to determine learning objectives while planning for their classes (lessons 1, 2, 5 and 13), and only the first two submissions contained procedures for assessing student learning. Two lesson plans presented the presence of more than one teacher in the development of the proposed class (Themes: "Industrial Revolution" and "Comparative Study of Culture in English-Speaking Countries”).

Two teachers did not describe the teaching strategies that they would adopt to develop their lessons (lessons plans 4 and 5). On the other hand, three explicitly adopted lectures in a traditional way for their classes (documents 9,11 and 15). On the other hand, two teachers chosen by the use projects or problems such as teaching strategies (lesson plans 2 and 3).

\section{Discussion}

In 2011, Brazil has overtaken the UK to become the world's sixth-largest economy and could become one of the four most dominant economies by the year 2050 (O’Neill, 2001). However, the weakness in the education system has been one of the main shortcomings of Brazil, putting at risk the country's ability to compete globally in the search for new investments and to adopt innovation-enhancing technologies already present in the country (Rodríguez, Dahlman, \& Salmi, 2008). To illustrate this scenario, a total of 65 countries, Brazil in 2009 reached only the 53rd position in OECD Programme for International Student Assessment (PISA-

http://www.pisa.oecd.org/). The OECD/PISA combines the assessment of domain-specific areas such as reading, mathematical and scientific literacy. In addition, an assessment of problem-solving skills is an element into PISA, defined as the ability of students "to solve real cross-disciplinary problems where the solution path is not obvious" (OECD, 2003).

Improving the quality of teachers education is a key factor for the country overcome the challenges of teaching in primary and secondary schools (Gatti \& Barreto, 2009, 2011). Although the vast majority of teachers stated that they know the meaning and consider how very important the development of an interdisciplinary approach to teaching (Table 2), it is noteworthy that 61 professionals considered that they had had poor training or did not have any knowledge about interdisciplinary education in their respective undergraduate studies (Table 2). This is an important result since the interdisciplinarity has crucial contribution to make in teaching and learning.

Interdisciplinary approaches are essential in the discussion about the complex ethical and social conflicts facing our society today (Develaki, 2008). Moreover, in Brazil, as in the United States of America in 2006, "school science curriculums cover an extensive list of topics in a superficial manner, with significant repetition from year to year" (Learning Science Like a Scientist, 2006). Therefore, an integrated curriculum that link disciplines as math, chemistry, physical sciences, and biology, is an alternative approach to successful science education.

On the other hand, we observed that graduate courses in some way promote interdisciplinary studies more than undergraduate courses (Figure 1), though this possibility is a seemingly paradox because this level of training is closely related to the specialties and disciplines. In this context, it is likely that interdisciplinarity is the result of increased political and academic demand intrinsic to graduation, forcing the teachers to seek more knowledge integration in order to comply with academic obligations. Limitations of this study make it impossible to explore a deeper analysis on this subject. Thus, we believe that further studies are necessary to elucidate this result, especially because it is a potential solution to interdisciplinary teacher training. Nevertheless, as a possible example for Brazil, teacher education in Finland, which has one of the world's best performing education systems, moved to the two-tier degree system since 1 August 2005 (Niemi \& Jakku-Sihvonen, 2006).

"The combination of a three-year Bachelor's degree and a two-year Master's degree in appropriate subjects and pedagogy to qualify teachers to teach in primary and secondary schools. The thirty-year tradition of education both class teachers and subject teachers in Finnish universities will continue. The basic qualification to teaching professions will still be the Master's degree” (Niemi \& Jakku-Sihvonen, 2006).

Another teacher education problem is the fact that many of the experts responsible for creating training courses for teachers believe that the proper domain of disciplinary knowledge overcomes the importance of didactic or pedagogical knowledge (Perrenoud \& Thurler, 2002). Moreover, there is a large gap between what is 
Table 3. Summary of lesson plans submitted by 15 teachers to develop interdisciplinary practice. The criteria for evaluation of the plan were: objectives, subjects and teachers involved strategies or teaching methodology and assessment.

\begin{tabular}{|c|c|c|c|c|c|c|}
\hline Doc & Theme & Objectives & Subjects & Teachers & $\begin{array}{l}\text { Teaching strategies } \\
\text { and methodologies }\end{array}$ & Evaluation \\
\hline 1 & $\begin{array}{l}\text { "Spanish Speaking } \\
\text { Countries" }\end{array}$ & $\begin{array}{l}\text { To know the culture } \\
\text { of Hispanic countries } \\
\text { in South America. }\end{array}$ & $\begin{array}{l}\text { Spanish, Geography, } \\
\text { History, hysical } \\
\text { Education and Art }\end{array}$ & Spanish (1) & $\begin{array}{l}\text { Divide the class into groups } \\
\text { addressing relevant issues to each } \\
\text { nation, such as cooking, sports, } \\
\text { politics, economy and tourism. }\end{array}$ & $\begin{array}{l}\text { Papers } \\
\text { Presentation } \\
\text { and test }\end{array}$ \\
\hline 2 & $\begin{array}{l}\text { "The Senses of } \\
\text { the Human Body" }\end{array}$ & $\begin{array}{l}\text { Recognition of the } \\
\text { importance of the } \\
\text { sense organs }\end{array}$ & $\begin{array}{l}\text { Biology, } \\
\text { Physics and } \\
\text { Chemistry }\end{array}$ & Biology (1) & $\begin{array}{l}\text { Development of group projects } \\
\text { by students and the use of lectures. }\end{array}$ & $\begin{array}{l}\text { Paper } \\
\text { presentations }\end{array}$ \\
\hline 3 & "Nanotechnology" & $\mathrm{NP}^{*}$ & $\begin{array}{l}\text { Biology, } \\
\text { Physics and } \\
\text { Chemistry }\end{array}$ & Biology (1) & $\begin{array}{l}\text { Texts studies and use of } \\
\text { "problems" that society } \\
\text { faces today (e.g., pollution, } \\
\text { energy and food) }\end{array}$ & $\mathrm{NP}^{*}$ \\
\hline 4 & "Vitamins" & $\mathrm{NP}^{*}$ & $\begin{array}{l}\text { Mathematics } \\
\text { and Biology }\end{array}$ & Mathematics (1) & $\mathrm{NP}^{*}$ & $\mathrm{NP}^{*}$ \\
\hline 5 & $\begin{array}{l}\text { "Nature in Brazil: } \\
\text { Climate and } \\
\text { Vegetation" }\end{array}$ & $\begin{array}{l}\text { Learning about the } \\
\text { relationship between } \\
\text { vegetation and climate. }\end{array}$ & $\begin{array}{l}\text { Physics, Biology, } \\
\text { Literature and } \\
\text { Geography }\end{array}$ & Geography (1) & $\mathrm{NP}^{*}$ & $\mathrm{NP}^{*}$ \\
\hline 6 & “Renaissance” & $\mathrm{NP}^{*}$ & $\begin{array}{l}\text { History, } \\
\text { Geography, } \\
\text { Science, } \\
\text { Literature } \\
\text { and Arts }\end{array}$ & Literature (1) & $\begin{array}{l}\text { Presentation of maps of Italy, } \\
\text { to present its topography and } \\
\text { hydrography, photos of paintings } \\
\text { and sculptures from the } \\
\text { Renaissance period, beyond the } \\
\text { presentation of the tragedy Romeo } \\
\text { and Juliet William Shakespeare. }\end{array}$ & $\mathrm{NP}^{*}$ \\
\hline 7 & $\begin{array}{l}\text { "Study of the } \\
\text { Numbers in } \\
\text { and } \\
\text { Portuguese" }\end{array}$ & $\mathrm{NP}^{*}$ & $\begin{array}{l}\text { English and } \\
\text { Mathematics }\end{array}$ & English (1) & $\begin{array}{l}\text { Students will learn how to } \\
\text { write and pronounce the } \\
\text { numbers } 1 \text { - } 100 \text { in English. }\end{array}$ & $\mathrm{NP}^{*}$ \\
\hline 8 & $\begin{array}{l}\text { "Industrial } \\
\text { Revolution” }\end{array}$ & $\mathrm{NP}^{*}$ & $\begin{array}{l}\text { History and } \\
\text { Physical } \\
\text { History, Physics, }\end{array}$ & $\begin{array}{l}\text { History (1) and } \\
\text { Physics (1) }\end{array}$ & $\begin{array}{l}\text { Use of texts and experience } \\
\text { (machine Heron) } \\
\text { Lecture, production of posters }\end{array}$ & $\mathrm{NP}^{*}$ \\
\hline 9 & “Industrialization” & $\mathrm{NP}^{*}$ & $\begin{array}{l}\text { Portuguese, } \\
\text { Geography and } \\
\text { Mathematics }\end{array}$ & Biology (1) & $\begin{array}{l}\text { by students about the benefits } \\
\text { and drawbacks of the processes } \\
\text { of industrialization. }\end{array}$ & $\mathrm{NP}^{*}$ \\
\hline 10 & $\begin{array}{l}\text { "Earth: Water } \\
\text { Planet" }\end{array}$ & $\mathrm{NP}^{*}$ & $\begin{array}{l}\text { Portuguese, } \\
\text { Literature } \\
\text { and Science. }\end{array}$ & $\begin{array}{l}\text { Portuguese (1) } \\
\text { Literature (1) }\end{array}$ & $\begin{array}{l}\text { From the novel "The Slum” by } \\
\text { Aluízio de Azevedo, held } \\
\text { discussions with students about } \\
\text { basic sanitation, potable water } \\
\text { conservation and prepare } \\
\text { educational pamphlets on the } \\
\text { subject. }\end{array}$ & $\mathrm{NP}^{*}$ \\
\hline 11 & $\begin{array}{l}\text { "The Process of } \\
\text { Industrialization" }\end{array}$ & $\mathrm{NP}^{*}$ & $\begin{array}{l}\text { Geography } \\
\text { and History }\end{array}$ & Geography (1) & Lecture. & $\mathrm{NP}^{*}$ \\
\hline 12 & $\begin{array}{l}\text { Comparative Study } \\
\text { of Culture in } \\
\text { English Speaking } \\
\text { Countries }\end{array}$ & $\mathrm{NP}^{*}$ & $\begin{array}{l}\text { English, } \\
\text { Geography } \\
\text { and Physical } \\
\text { Education }\end{array}$ & $\begin{array}{l}\text { English (1), } \\
\text { Geography (1) } \\
\text { and Physical } \\
\text { Education (1). }\end{array}$ & $\begin{array}{l}\text { Comparative study of culture } \\
\text { and different English speaking } \\
\text { countries, and the implementation } \\
\text { of a tournament with the most } \\
\text { popular sports in countries } \\
\text { where they speak English. }\end{array}$ & $\mathrm{NP}^{*}$ \\
\hline 13 & $\begin{array}{l}\text { "Principles } \\
\text { of Inertia" }\end{array}$ & $\begin{array}{l}\text { Construction by } \\
\text { students of the } \\
\text { concept of inertia. }\end{array}$ & $\begin{array}{l}\text { Physics and } \\
\text { Biology }\end{array}$ & Physics (1) & $\begin{array}{l}\text { Classroom practice-there was no } \\
\text { specification of the class by the } \\
\text { teacher. }\end{array}$ & $\mathrm{NP}^{*}$ \\
\hline 14 & $\begin{array}{l}\text { Regions } \\
\text { of Brazil” }\end{array}$ & $\mathrm{NP}^{*}$ & $\begin{array}{l}\text { Mathematics and } \\
\text { Geography }\end{array}$ & Mathematics (1) & $\begin{array}{l}\text { Presentation of the five regions of } \\
\text { Brazil and providing a table with } \\
\text { demographic data of these } \\
\text { regions. In this context, present } \\
\text { a questionnaire that requires the } \\
\text { student, among other issues, the } \\
\text { construction of graphs. }\end{array}$ & $\mathrm{NP}^{*}$ \\
\hline 15 & $\begin{array}{l}\text { "Mathematics } \\
\text { and Other } \\
\text { Disciplines" }\end{array}$ & $\mathrm{NP}^{*}$ & $\begin{array}{l}\text { Mathematics, } \\
\text { Biology, } \\
\text { Portuguese, } \\
\text { Chemistry } \\
\text { and History }\end{array}$ & Mathematics (1) & $\begin{array}{l}\text { Lectures where content from } \\
\text { different disciplines would be } \\
\text { explored in association with } \\
\text { content of mathematics. }\end{array}$ & $\mathrm{NP}^{*}$ \\
\hline
\end{tabular}

Note: "NP: Not presented by the teacher. 
prescribed in the training courses and the reality of the profession (Perrenoud \& Thurler, 2002). In the United States, Futrell (2010) points the "Teacher Residency Model to Support Preservice Teachers" as a way to mitigate these problems in teacher education programs. The model is an alternative to improve teacher education to work in primary and secondary education by building a curriculum where the students-future teachers-may be confronted with situations more closely than they will encounter in their future activities. This includes the early participation in real educational settings under the supervision of experienced teachers in different contexts and schools. Thus, training of teachers within an interdisciplinary perspective, since the beginning of their professional education, might favor the implementation of these practices when they come to perform their professional activities.

"A strong residency model includes a pool of experienced teachers serving as a collaborators and mentors for the residents. The model is founded on the belief that preservice teachers in these programs (known as residents) must spend at least one year in a mentoring relationship in a highly competent teacher's classroom” (Futrell, 2010).

The development of more flexible undergraduate curriculums is important to enable students' interdisciplinary education. The Brazilian Academy of Science believes that interdisciplinary education can be more easily achieved with short learning cycle courses (Chaves et al., 2004). This can be accomplished by a maximum two-year Basic Cycle, followed by a Professional Cycle. The Basic Cycle should be divided in three major areas: Basic Sciences and Engineer; Life Sciences; and Arts, Humanities and Social Studies (Chaves et al., 2004). In this context, The School of Arts, Sciences and Humanities of the University of São Paulo (EACH/USP) has an academic project characterized by having a one-year basic cycle, which seeks to articulate specific disciplines and interdisciplinary areas with scientific, cultural and professional formation through projects and problem solving (Araújo \& Arantes, 2009).

Our data indicate that teachers believe that schools do not provide favorable conditions for the implementation of interdisciplinary practices in their curricula (Table 2). Lam, Cheng, \& Choy (2010), in a study conducted in Hong Kong, demonstrated that when schools are stronger in collegiality and more supportive of teachers competence and autonomy, teachers had more motivated to develop and consolidate new teaching strategies, such as the use of project-based learning and interdisciplinary teaching.

The information presented in Table 2 are also similar to studies conducted with teachers from public schools in State of São Paulo-Brazil (Augusto \& Caldeira, 2007; Augusto, Caldeira, Caluzi, \& Nardi, 2004). The studies highlight the main difficulties experienced by those teachers in the implementation of interdisciplinary practices in their institutions, namely: a) absence of time and difficulty to hold meetings on pedagogical planning; b) lack of sources for research on the topic of "interdisciplinarity"; c) lack of material resources or adequate physical spaces in schools; d) difficulties of relationship and interaction with the school administration; e) the absence of pedagogic coordination; and f) students' indifference and a lack of discipline. In this sense, we agree with these authors who state that although there is a difficulty in developing interdisciplinary projects, it is not uncommon for teachers to use excuses for not updating the knowledge on innovative teaching practices.

A contradictory result can be seen in relation to the teachers' performances in the pursuit of interdisciplinary lessons at their respective disciplines. Table 2 shows that 59 teachers, out of the 101 that took part on this study, prepared interdisciplinary activities to develop their lessons, compared to the remaining 42 teachers who said they did not. However, an inconsistency is highlighted when we compare these results with those presented, which shows that only five teachers answered that interdisciplinary education was very common in their educational institutions, whereas, on the other hand, 86 reported that interdisciplinary practice was not currently practiced in their schools. Besides that, these results are inconsistent with the analysis of lesson plans developed by 15 teachers, since they do not show evidence of refined knowledge about teaching interdisciplinary (Table 3).

Table 3 indicates that teachers persist in the idea of working alone in the development of interdisciplinary practices. Nevertheless, preferably the planning and implementation of interdisciplinary are collaborative activities must occur between two or more teachers (Spalding, 2002). Although we admit that many teachers have the competence to conduct classes that address specific knowledge of different areas, we advocate dialogue and effective working between teachers from different areas (disciplines) to build interdisciplinary lessons. Cooperative work tends to increase classroom potential in an interdisciplinary perspective (Alves, Silva-Filho, \& Lopes, 2009). Besides, knowledge, skills and professional competence of others tend to create better conditions for the student's learning. Even so, it is not uncommon to find teachers' resistance to working with peers. Although isolated activities of some teachers have pedagogical value, it is noteworthy that for an interdisciplinary project 
to work at a school, it is central to have the engagement of a number of teachers (Schimidt, Fonseca, \& Alves, 2005), because it does require, among other issues, regular meetings for planning, implementing and evaluating.

Problems encountered with the analysis of lessons plans to ratify the problem of poor teaching education of primary and secondary education in Brazil (Gatti \& Barreto, 2011). The planning of teaching strategies in the should be carried out with defined learning objectives (conceptual, procedural and attitudinal), which in turn should be connected with instruments and procedures for appropriate evaluation of student learning (BIE, 2008; Bordenave \& Pereira, 2005).

Brazil's Ministry of Education (MEC) states that interdisciplinarity should be implemented due to a necessity in the school environment felt by the actors, i.e. principals, teachers and students. MEC suggests processes such as project development for the construction of interdisciplinary work in the school environment (Brasil, 1998). However, only two of the teachers that elaborated lesson plans adopted strategies that could be related to "Project-Based Learning” or "Problem-Based Learning”, which facilitate an interdisciplinary approach and allow a positive effect on students’ skills development (Dochy, Segers, Van den Bossche, \& Gijbels, 2003; Lam, Cheng, \& Choy, 2010; Savery, 2006).

There is extensive literature available on these teaching methodologies for Higher Education (Hmelo-Silver, 2004; Mamede \& Penaforte, 2001; Rikers \& Brum, 2006). However, in Brazil, these practices are still incipient, and a more dramatic scenario is observed in the employment of these methodologies at regular high school and professional secondary education level (Lopes et al., 2011). In addition, a study by Silva-Filho and colleagues shows the lack of specific publications in Portuguese, or from Brazilian researchers, on the use of the Problem-Based Learning (PBL) application and the training of teachers to employ it in primary and secondary education in Brazil (Silva-Filho, Lopes, Alves, \& Figueiredo, 2010). This is a relevant finding because as more material is made available and easily accessible on these methodologies, the greater the probability that education professionals will be empowered to implement teaching strategies that are efficient for the development of interdisciplinary programs in schools and universities.

\section{Conclusion}

This study provided evidence that interdisciplinary practices in secondary schools in Rio de Janeiro are not frequent, even with the majority of teachers indicating that its use is important and must be recommended and encouraged by Brazil's Ministry of Education. We were able to verify that teachers realize there are deficiencies in school's organizational structure and that they have little support of the school management board to develop such practices. On the other hand, we found out dearth on teachers' abilities to develop interdisciplinary approaches in the classroom.

Nowadays, it is essential to work effectively as a team to solve problems in different contexts using critical thinking and analyzing and synthesizing information. However, there is little evidence that current educational systems are adequately fulfilling these goals in Brazil. We believe that methodologies such as Problem-Based Learning, Project-Based Learning and Investigative Case Based Learning may be important strategies to transform teacher education programs in Brazil. In addition, the continuing education of these professionals is essential through postgraduation programs.

\section{References}

Alves, N. G., Silva-Filho, M. V. S., \& Lopes, R. M. (2009). Interdisciplinaridade no Ensino Técnico: Um Caminho Possível. Politécnica de Saúde Joaquim Venâncio, 3, 179-195.

Araújo, U. F., \& Arantes, V. A. (2009). Comunidade, Conhecimento e Resolução de Problemas: O Projeto Acadêmico da USP Leste. In U. F. Araújo, \& G. Sastre (Eds.), Aprendizagem Baseada em Problemas (Vol. 1, pp. 101-121). São Paulo: Summus. (Reprinted from: NOT IN FILE)

Augusto, T. G. S., \& Caldeira, A. M. A. (2007). Dificuldades Para a Implantação de Práticas Interdisciplinares em Escolas Estaduais, Apontadas por Professores da Área de Ciências da Natureza. Investigações em Ensino de Ciências, 12, 139154.

Augusto, T. G. S., Caldeira, A. M. A., Caluzi, J. J., \& Nardi, R. (2004). Interdisciplinaridade: Concepções de Professores da Ârea Das Ciências da Natureza em Formação em Serviço. Ciência e Educação, 10, 277-289.

http://dx.doi.org/10.1590/S1516-73132004000200009

Azer, S. A. (2009). Problem-Based Learning in the Fifth, Sixth, and Seventh Grades: Assessment of Students’ Perceptions. 
Teaching and Teacher Education, 25, 1033-1042. http://dx.doi.org/10.1016/j.tate.2009.03.023

Bialek, W., \& Botstein, D. (2004). Introductory Science and Mathematics Education for 21st-Century Biologists. Science, 303, 788-790. http://dx.doi.org/10.1126/science.1095480

BIE (2008). Aprendizagem Baseada em Projetos: Guia Para Professores do Ensino Fundamental e Médio. Rio Grande do Sul Artmed Editora.

Bordenave, J. D., \& Pereira, A. M. (2005). Estratégias de Ensino-Aprendizagem (26th ed.). Petrópolis, RJ: Editora Vozes.

Brasil (1998). Ministério da Educação. Parecer do Conselho Nacional de Educação/Câmara de Educação Básica. Diretrizes Curriculares Nacionais Para o Ensino Médio. PARECER CNE/CEB No. 15/1998

Brewer, G. D. (1999). The Challenges of Interdisciplinarity. Policy Sciences, 32, 327-337. http://dx.doi.org/10.1023/a:1004706019826

Chaves, A. S., Filho, C. A. A., Barreto, F. C. S., Velho, G. C. A., Jornada, J. A. H., Bevilacqua, l., Davidovich, L., Nussenzveig, M., \& Gattass, R. (2004). In Brazilian Academy of Science, Rio de Janeiro, 1-40.

Develaki, M. (2008). Social and Ethical Dimension of the Natural Sciences, Complex Problems of the Age, Interdisciplinarity, and the Contribution of Education. Science \& Education, 17, 873-888. http://dx.doi.org/10.1007/s11191-007-9077-7

Dochy, F., Segers, M., Van den Bossche, P., \& Gijbels, D. (2003). Effects of Problem-Based Learning: A Meta-Analysis. Learning and Instruction, 13, 533-568. http://dx.doi.org/10.1016/S0959-4752(02)00025-7

Fazenda, I. C. A. (2002). Interdisciplinaridade: História, Teoria e Pesquisa (10th ed.). Campinas, SP: Papirus Editora.

Freire, P. (1987). Pedagogia do Oprimido (17th ed.). São Paulo: Paz e Terra Press.

Futrell, M. H. (2010). Transforming Teacher Education to Reform America's P-20 Education System. Journal of Teacher Education, 61, 432-440. http://dx.doi.org/10.1177/0022487110375803

Gatti, B. A., \& Barreto, E. S. (2009). Professores do Brasil: Impasses e Desafios (Vol. UNIESCO, pp. 1-294). Brasilia: Organização das Nações Unidas para a Educação, a Ciência e a Cultura (UNESCO).

Hamburger, E. W., Galembeck, F., Barbosa, J. L. M., Tenenblat, K., Davidovich, L., Beirao, P. S. R. L., \& Schwartzman, S. (2007). Ensino de Ciências e Educação Básica: Propostas Para um Sistema em Crise (pp. 1-47). Rio de Janeiro: Academia Brasileira de Ciências.

Hill, M. M., \& Hill, A. (2005). Investigação por Questionário ( 2nd ed.). Lisboa: Edições Sílabo.

Hmelo-Silver, C. E. (2004). Problem-Based Learning: What and How Do Students Learn? Educational Psychology Review, 16, 235-266. http://dx.doi.org/10.1023/B:EDPR.0000034022.16470.f3

Klein, J. T. (2006). A platform for a Shared Discourse of Interdisciplinary Education. Journal of Social Science Education, 5 , $10-18$.

Koizumi, H. (2004). The Concept of "Developing the Brain”: A New Natural Science for Learning and Education. Brain Development, 26, 434-441. http://dx.doi.org/10.1016/j.braindev.2003.09.011

Krishnan, A. (2009). Five Strategies for Practising Interdisciplinarity. ESRC National Centre for Research Methods, 1-11.

Lam, S.-f., Cheng, R. W.-Y., \& Choy, H. C. (2010). School Support and Teacher Motivation to Implement Project-Based Learning. Learning and Instruction, 20, 487-497. http://dx.doi.org/10.1016/j.learninstruc.2009.07.003

Lattuca, L. R. (2003). Creating Interdisciplinarity: Grounded Definitions from College and University Faculty. History of Intellectual Culture, 3, 1-20.

Learning Science Like a Scientist (2006). Nature Chemical Biology, 2, 503-503. http://dx.doi.org/10.1038/nchembio1006-503

Lopes, R. M., Silva Filho, M. V., Marsden, M., \& Alves, N. G. (2011). Aprendizagem Baseada em Problemas: Uma Experiência no Ensino de Química. Quimica Nova, 34, 1275-1280.

Mamede, S., \& Penaforte, J. (2001). Aprendizagem Baseada em Problemas: Anatomia de uma Abordagem Educacional (Vol. 1). Fortaleza: Hucitec.

Mansilla, V. B. (2005). Assessing Student Work at Disciplinary Crossroads. Change: The Magazine of Higher Learning, 37, 14-21. http://dx.doi.org/10.3200/CHNG.37.1.14-21

MEC (2009). Matriz de Referência Para o Enem 2009. http://www.enem.inep.gov.br/pdf/Enem2009 matriz.pdf

Morin, E. (2000). Os Sete Saberes Necessários à Educação do Futuro Edições UNESCO (pp. 1-115). Brasília, DF: UNESCO.

National Environmental Policy Act of 1969, 42 § 1983 102-105 (1994 May 15, 1969).

Niemi, H., \& Jakku-Sihvonen, R. (2006). In the Front of the Bologna Process: Thirty-Years of Research-Based Teacher Education in Finland. Posodobitev Pedagoških Študijskih Programov v Mednarodnem Kontekstu: Modernization of Study Programmes in Teachers' Education in an International Context (pp. 50-69). Ljubljana: Univerza v Ljubljani, Pedagoška 
Fakulteta.

Nikitina, S. (2006). Three Strategies for Interdisciplinary Teaching: Contextualizing, Conceptualizing, and Problem Centring. Journal of Curriculum Studies, 38, 251-271. http://dx.doi.org/10.1080/00220270500422632

Nissani, M. (1997). Ten Cheers for Interdisciplinarity: The Case for Interdisciplinary Knowledge and Research. The Social Science Journal, 34, 201-216. http://dx.doi.org/10.1016/S0362-3319(97)90051-3

O’Neill, J. (2001). Building Better Global Economic BRICs (pp. 1-16). London: Goldman Sachs Economic Research Group.

OECD (1972). Interdisciplinarity: Problems of Teaching and Research in Universities. Washington, DC: OECD Publications Center.

OECD (2003). The PISA 2003-Assessment Framework-Mathematics, Reaging, Science and Problem Solving Knowledge and Skills (p. 200). Organisation for Economic Co-Operation and Development.

Perrenoud, P., \& Thurler, M. G. (2002). A Formação dos Professores no Século XXI As Competências Para Ensinar no Século XXI (pp. 11-33). Porto Alegre: Artmed. (Reprinted from: NOT IN FILE)

Rikers, R. M. L. P., \& Brum, A. B. H. (2006). Introduction to the Special Issue on Innovations in Problem-Based Learning. Advances in Health Sciences Education, 11, 315-319. http://dx.doi.org/10.1007/s10459-006-9011-9

Rodríguez, A., Dahlman, C., \& Salmi, J. (2008). Knowledge and Innovation for Competitiveness in Brazil. Washington, DC: The International Bank for Reconstruction and Development/The World Bank. http://dx.doi.org/10.1596/978-0-8213-7438-2

Savery, J. (2006). Overview of Problem-Based Learning: Definitions and Distinctions. The Interdisciplinary Journal of Problem-Based Learning, 1, 9-20.

Schimidt, E. F. C., Fonseca, P. C., \& Alves, L. A. (2005). A Prática da Interdisciplinariedade em Sala de Aula: Um Estudo Exploratório, Utilizando Vírus Como Modelo. Atas do Encontro Nacional de Pesquisa em Educação em Ciências, 20, $12-24$.

Serdyukov, P., \& Ryan, M. (2008). Writing Effective Lesson Plans: The 5-Star Approach. Boston: Allyn \& Bacon.

Silva-Filho, M. V., Lopes, R. M., Alves, N. G., \& Figueiredo, L. M. S. (2010). Como Preparar os Professores da Educação Básica Para a Aprendizagem Baseada em Problemas. http://each.uspnet.usp.br/pbl2010/trabs/trabalhos/TC0145-1.pdf

Spalding, E. (2002). Of Organelles and Octagons: What Do Preservice Secondary Teachers Learn from Interdisciplinary Teaching? Teaching and Teacher Education ,18, 699-714. http://dx.doi.org/10.1016/S0742-051X(02)00029-X

Tadmor, B., \& Tidor, B. (2005). Interdisciplinary Research and Education at the Biology-Engineering-Computer Science Interface: A Perspective (Reprinted Article). Drug Discovery Today, 10, 1706-1712. http://dx.doi.org/10.1016/S1359-6446(05)03702-5

Wingreen, N., \& Botstein, D. (2006). Back to the Future: Education for Systems-Level Biologists. Nature Review Molecular Cell Biology, 7, 829-832. http://dx.doi.org/10.1038/nrm2023 